\title{
Türkistanlı Hacıların Ziyaret Merkezi Olarak İstanbul ${ }^{*}$
}

\section{Yusuf Sannay $^{* *}$}

öz

Osmanlı Devleti ile Türkistan bölgesi arasındaki ilişkiler siyasi alandaki kopukluklara rağmen, kültürel ve dini bağlar ile tarihi arka plandan dolayı devam etmiştir. Bu ilişkilerin önemli bir göstergesini de Türkistan bölgesinden hac yolculuğuna çıkan Türklerin Hilafet merkezi olan İstanbul'u ziyaret etmeleri ve dönüşlerinde de aynı güzergahı takip etmeleri oluşturmaktadır. Osmanlı Devleti de Türkistan bölgesinden gelen hacıların İran ve Rusya faktörü sebebiyle yol güvenliklerinin sağlanması ile İstanbul'daki konaklama ve hac yolculuğu sırasındaki masrafların karşılanmasını bir devlet politikası haline getirmiştir.

Makalede Türkistan bölgesinden gelen hacıların İstanbul üzerinden Hicaz'a gitmeleri ve bu konuda Osmanlı Devleti’nin politikası arşiv belgelerine dayanılarak değerlendirilmektedir.

\section{Anahtar Kelimeler}

Osmanlı Devleti, İstanbul, Türkistan, Türkistanlı hacılar, Türkistan elçileri, Buhara, Kaşgar.

Geliş Tarihi: 23 Kasım 2016 - Kabul Tarihi: 11 Haziran 2017

Bu makaleyi şu şekilde kaynak gösterebilirsiniz:

Sarınay, Yusuf (2019). “Türkistanlı Hacıların Ziyaret Merkezi Olarak İstanbul”.

bilig - Türk Dünyası Sosyal Bilimler Dergisi 88: 1-18.

* Prof. Dr., TOBB Üniversitesi, Fen-Edebiyat Fakültesi, Tarih Bölümü - Ankara/Türkiye

ORCID ID: https://orcid.org/0000-0002-6486-3417

ysarinay@etu.edu.tr 


\section{Hicaz'da Osmanlı Egemenliği, Hilafet ve Osmanlı Devleti’nde Hac Organizasyonu}

Fatih döneminde batıya doğru ilerleyişini büyük ölçüde tamamlayan Osmanlı Devleti I. Selim döneminde güneye doğru yönelmiş, burada önemli bir güç olan Memlukları 1517 tarihinde ortadan kaldırmıstır. Memlukluların ortadan kaldırılması ile Suriye, Filistin, el-Cezire, Hicaz ve Mısır Osmanlı topraklarına katılmıştır (Uzunçarşılı 1972: 292). Bu sefer sonunda I. Selim Abbasi halifesi III. Mütevekkil Alellah’ı İstanbul'a getirerek hilafeti devr almıştır (Uzunçarşılı 1972: 294). ${ }^{1}$ Yavuz Kahire'de iken Mekke emiri Şerif Berekat, oğlu ve bir elçiyi göndermiştir. Elçilik heyeti Osmanlı otoritesini benimsemesinin ifadesi olarak Mekke’nin anahtarları ve bazı kutsal emanetleri Osmanlı padişahına vermiştir. Faroqhi, Kutbeddin'e atıfla Hicaz’ ın Osmanlı egemenliğine geçiş sürecinde, bu bölgenin iaşe kaynağı olan Mısır ile bağlantısının Portekizliler tarafından kesildiğinde yaşanılan sıkıntının ciddi boyutlarda olduğunu ifade eder. Kutbeddin'deki kayda göre "bu dönemde Haremeyn-i Şerifeyn, neredeyse tümüyle Mısır'dan gelecek gıda maddelerine bağımlıdd. Bunun bir sonucu olarak, 16. yüzyılın başında Portekizlilerin Kızıldeniz’e sık sık yaptıkları saldırılar yüzünden iki bölge arası ilişkilerin kısa dönemli kopması bile, paniğe ve denetlenemeyen fiyat artışlarına yol açıyordu." (Faroqhi 2008: 35). Yine aynı kaynağa göre, Mekke emirinin Osmanlı sultanına oğlunu göndermesinin böyle bir ekonomik-politik arkaplanı vardır. Yavuz da Berekat'a verilmek üzere heyete Mekke Emirliği fermanını teslim etmiştir. Bu tarihten itibaren Mekke, Medine ve Hicaz’n diğer bölgelerinde hutbe Osmanlı padişahlarının adlarına okunmaya başlanmış; böylece Osmanlı sultanları Harameyn'in hâdimi ve Hicaz bölgesinin hâkimi olmuşlardır (Kurşun 1999: 316). I. Selim'den itibaren Hâdimü'l-Haremeyn tanımı elkab olarak kullanılmıştır.

Böylece Osmanlı padişahları siyasi otoritelerinin yanında dini otoritenin de birleşmesi ile İslam dünyasının en büyük gücü haline gelmişlerdir. Bu ortamın oluşmasından itibaren de Osmanlı padişahları hac yolculuğuna çıkanların güvenliklerinin sağlanmasını kendilerinin en önemli görevleri arasında addetmişlerdir. Hac güvenliği kapsamındaki önlemler, Hicaz bölgesindeki Osmanlı varlığının devamı için de önemli görülmüştür. Esas olarak bakıldığında, hac organizasyonu ve güvenliği ile ilgili yapılan harcamalar, geri dönüşü olan harcamalar olmadığından hâdim unvanı, esasen söylemden ibaret değildi. Aksine 
Osmanlı egemenliğinin toplumsal meşruiyeti noktasında önemli bir yer işgal ediyordu (Faroqhi 2008: 9). ${ }^{2}$

Bu noktada, Osmanlı döneminde hac organizasyonunun nasıl gerçekleştiği ve güvenliğinin nasıl sağlandığına dair bilgiler (Özcan 1996: 400-408) bu sürecin işleyişini anlamak açısından önem taşımaktadır. Abbasi döneminde hacıların toplanma merkezi Bağdat idi. Tüm uzak yerlerden gelen hacılar Bağdat'ta toplanarak güvenli bir şekilde kutsal topraklara ulaşırlardı. Osmanlı Devleti Hicaz’ı kendi topraklarına dâhil etmesini müteakiben İslam dünyasında hacca ilişkin tüm sorumlulukları da üstlenmiş oldu. Artık İstanbul'un hacıların toplanma merkezi olduğu bu dönemde hacılar Şam ve Kahire yolu ile bir de Yemen, Bağdat-Basra yollarını kullanarak üç ana güzergah üzerinden Hicaz’a ulaşmaktaydılar. Anadolu, Rumeli, Türkistan ve Kafkasyảdan İstanbul'da toplanan hacılar Üsküdar, Gebze, Eskişehir, Konya ve Torosları geçerek Halep'e uzanır oradan Şam, Maan hattından Medine'ye ulaşırlar müteakiben Mekke'ye vararak bu seyahati tamamlamış olurlardı. Diğer yol ise deniz yolu ile Mısır üzerinden sağlanmakta idi. 1869'da Süveyş Kanalı'nın açılması ile karadan yapılan seyahatler büyük ölçüde yerini deniz yoluna bırakmıştır.

Organizasyon açısından, Osmanlılar'ın ana hatlarıyla Memluk Devleti'nin uyguladığı hac organizasyonunu tatbik ettikleri bilinmektedir (Özcan 1996: 401). Memlukler'de XV. yy’ın başından itibaren düzenli bir yolculuk haline getirilen hac seyahatinde en yetkili devlet görevlisi olarak Emîr-i Hac bulunmaktaydı. ${ }^{3}$ Bir kethüda ve bir kâtibin yardımcılığını yaptığı emîr-i hac ile birlikte hac kervanının güvenliğ̈ini sağlamak üzere görevlendirilmiş bir askerî birlik eşlik etmekteydi. Osmanlı dönemi hac organizasyonunda genellikle bir yeniçeri bölüğü veya timarlı sipahi birliğiyle birlikte birkaç top arabası da hacı adaylarına eşlik ederdi. Kanuni dönemindeki hac kervanlarında 150 yeniçeri ve 100 sipahinin yerlerini aldıkları bilinmektedir (Özcan 1996: 403). Bu sayı, güzergahtaki tehlikelerin arttığı dönemlerde duruma göre artış gösterebilmekteydi. XVII. ve XVIII. yüzyıllarda hac kafilelerinin güvenliğini hafif süvari birlikleri olan cerde birlikleri sağlamış, XIX. yy’n ikinci yarısından itibaren de düzenli ordu mensubu askerler bu görevi devralmıştır. Padişahın hediyelerini iletmek üzere görevli olan bir emin ile subaşının yanısıra, bir kadı da hac kafilesinde görevliydi. Devletin bu görevlilerine, işlerinde yardımcı olacak çeşitli alt kademe görevliler de vardı. Haccın gerçekleşebilmesi için söz konusu devlet görevlileri nezaretinde yapılan yolculuk sürecinde de gerek 
güvenlik gerekse temel ihtiyaçların sağlanması noktasında Osmanlı devletinin desteği devam etmekteydi.

Osmanlı Devleti sınırları içinde yer alan Hicaz’a, - haliyle - başka devletlerin tebaasından da Müslüman hacı adayları gelmekteydi. Ağırlıklı olarak İran, Hindistan ve Türkistan coğrafyalarından gelen bu hacıların güvenliği ve hac organizasyonu yine Osmanlılar’ın sorumluluğundaydı. Osmanlı Devleti bu hususta yaptığı askeri ve siyasi girişimleri gerekli durumlarda ilgili devletlere mektuplar yazarak bildirmiştir. Sultan II. Selim 1573 yılında Buhara Hanı Abdullah Han'a gönderdiği mektubunda hac yolunun güvenliğini sağlamaya çalıştığını, Akdeniz'de hacılar ve tüccarlara karşı korsanlık yapan Venedikliler'e karşı Kıbrıs' ın fethedildiğini bildiren bir mektup göndermiştir (BOA, A.DVNS.MHM.d, 21/465). Söz konusu bölgelerden gelen hacıların durumları, mevcut siyasal gelişmelerden de önemli ölçüde etkilenmekteydi. İran'la olan siyasi ve askeri mücadele, döneme göre farklı bir tavır almayı gerektiriyordu. Buna açık bir örnek olarak Osmanlı-İran savaşları dönemlerinde İran'dan hacı adaylarının Osmanlı topraklarına girişlerine müsaade edilmemesi verilebilir (Özcan 1996: 404, Faroqhi 2008: 153). Sonraki dönemler de İranlı hacıların ciddi bir kontrole tabi tutuldukları bilinmektedir. Türkistan bölgesinden gelen hacılarla ilgili durum ise hac için izledikleri güzergâhla ilgiliydi. Hicaz’a ulaşımları ise esas olarak Rusya ve İran coğrafyası üzerinden gerçekleştiğinden, Türkistan hacılarının durumu Osmanlı ile bu devletler arasındaki ilişkilerde yaşanan sorunlar veya savaş hallerine göre şekilleniyordu. Buhara ve Semerkant'ta toplanarak Hazar kıyısından önce Astrahan'a varan Türkistanlı hacı adayları, buradan Osmanlı topraklarına Kefe ve Özi'den girer, deniz yoluyla da İstanbul'a geçerek hac kervanına katılırlardı (Özcan 1996: 405, McChesney 2003: 132). ${ }^{4}$ Osmanlı Devleti'nin siyasal ve askeri mücadelelerinden etkilenmelerine en dikkat çekici örnek olarak Astrahan' ın Ruslar'ın eline geçmesi gösterilebilir. ${ }^{5}$ II. Selim Rus işgaline giren Astrahan'a bir sefer düzenleyerek burayı ele geçirmek istemiş fakat başarılı olamamıştı (Özcan 1996: 382). Türkistanlı hacılar güzergâhlarındaki önemli bir durak olan Astrahan'ın Ruslar tarafından alınmasıyla kuzey yolunu kullanmak durumunda kalmışlar, bu durum hem yollarını uzatmış, hem de daha tehlikeli bir yol izlemelerine neden olmuştur. Rus toprakları dışında bir başka dönüş güzergâhı da İran toprakları idi. Ancak bu yolda çok güvenli değildi. İran 1568 yılında Harezmli hacıları hapsetmiş, Osmanlı Devleti de hapse atılan hacıları kurtarmak için diplomatik girişimlerde bulunmuştur (BOA, A.DVNS.MHM.d, 7/2723). Gerek Astrahan'la 
bağlantılı olarak gerekse Safevi tehlikesi neticesinde Osmanlı Devleti’nin Türkistanlı hacıların güvenliğine dönük tedbirleri ve Türkistan hanlıkları ile bu bağlamdaki ilişkilerinin temelinde söz konusu güzergâhta yaşanan sorunlar olduğu arşiv kayıtlarında sıkça dile getirilen bir husustur.

Osmanlı Devleti ile Türkistan arasındaki ilişkilerin başlangıcına bakıldığında ise elimizdeki en erken tarihli belge 1568 tarihlidir. Ancak sadece bu belgeye bakarak daha önceki tarihlerde ilişkilerin olmadığı söylenemez (BOA, A.DVNS.MHM.d, 7/667). Büyük Selçuklular döneminde Türkistan'dan başlayarak Anadolu’ya kadar devam eden Müslüman Türk hâkimiyeti İran'da XVI. asırda Şiiliğin güçlenmesi ile coğrafi olarak bölünmeye uğramıstır. İran’n Şii bir güç olarak ortaya çıkışı ile her ikisi de Sünni olan Osmanlı Devleti ile Türkistan hanlıkları arasındaki işbirliği kanalları açılmıştır. Bu işbirliğinin en güçlü örneği 1578 yılında Osmanlı-İran savaşında İran’a karşı yapılan Osmanlı-Özbek ittifakıdır. Bu ittifak çerçevesinde Buhara Hanı Abdullah, Meşhed ve Nişabur'a askeri harekât düzenleyerek Osmanlı Devleti'ne yardımcı olmuştur (Saray 1984: 3). Bu ittifak dışında ciddi bir askeri ve siyasal işbirliği olmamış, XVI. yüzyıldan itibaren Osmanlı Devleti ile Türkistan arasındaki münasebetlerde İran ve Rusyảnın baskın etkisi daima kendisini hissettirmiştir. XVI. yüzyılda Safeviler, XVII. yüzyılda ise Rusya daha ağırlıklı olmak üzere Türkistan’ın Osmanlı ile bağlantısını engelleyen ana aktörlerdir (Andican 2009: 199200). Osmanlı Devleti'nin bu iki önemli gücü daima dikkate almak zorunda kalması sebebiyle Türkistan’la ilişkiler sosyal ve kültürel düzeyden siyasal ve ekonomik seviyeye geçememiştir. Bir başka deyişle, Osmanlılar'ın bölge ile ilişkisini aralarında yer alan coğrafi bölgelerin egemen güçleri ile arasındaki gergin ilişkiler belirlemiştir.

\section{Hac Yolunun Bir Parçası Olarak İstanbul}

Türkistan'dan Hicaz'a hac yolculuğunda, bahsi geçen siyasal etkenlerin belirleyiciliği ve etkisinin yanısıra, dikkati geçen ve altının çizilmesi gereken en önemli noktalardan biri, İstanbul'un Türkistanlı hacıların yolculuklarının temel bir parçası olmasıdır. Türkistanlı hacıların İstanbul'a hac yolunda uğramalarına ilişkin ilk kayıtlar ise XVI. yüzyıldandır (BOA, A.DVNS.MHM.d, 7/671). Bu tarihte hacılar Buhara ve Semerkant'tan ayrılmalarını müteakib Hazar Denizine ulaşmakta Astrahan üzerinden Kırım’a oradan da Kuzey Karadeniz kıyısındaki Kefe, Anapa, Azak ve Özi limanları vasıtasıyla deniz yoluyla İstanbul'a gelmekteydiler. Yollarını bu denli uzatmak istemeyen bir kısım 
hacı adayları ise Karadeniz kıyısındaki Sinop veya Samsun limanlarına gelip, İstanbul'dan Şam istikametinde yola çıkan hac kervanıyla Eskişehir-Konya taraflarında buluşmak üzere kara yoluyla yolculuklarına devam ederlerdi. ${ }^{6}$ Kazandıracağı zamanın çok olmaması ve izlenilen kara yolunun zorluğu göz önüne alındığında çok bir avantaj oluşturmayan bu istikametin Türkistanlı hacı adaylarının pek de tercih etmediği bir yol olduğu düşünülmektedir (Faroqhi 2008: 168-169, Kütükçü 2011: 186). ${ }^{7}$ Doğu Türkistan'ın bir şehri olan Kumul'dan bu seyahat XIX. yy'da 100 günde tamamlanmakta idi (BOA, Y.PRK.AZJ, 51/70). ${ }^{8}$

En kestirme yollardan gidildiği zaman dahi her bakımdan günümüz şartları ile mukayese edilemeyecek derecede zorluklarla dolu böyle bir yolculuğa bir de ilave olarak İstanbul niçin eklenmekte idi? Kumul Kadısı, Kumul Müftüsü ve Turfan Kadısının Sultan II. Abdülhamid'e müştereken sundukları raporda bu sorunun cevabı olabilecek bir bölüm bulunmaktadır. 1906 tarihli olduğunu tahmin ettiğimiz rapor iki sayfadır. Raporun ilk iki sayfası Kaşgar’ın beşeri, sosyal, iktisadi ve siyasi özelliklerine ilişkindir. Rapor'un hissiyat bölümünde halkın kuvvetli bir inançla hilafet makamına dini ve manevi bakımdan bağlı oldukları belirtilmektedir. Bu inançla hac görevinden önce halifenin ziyaret edilmesinin dini vecibe olarak bilindiği ve halifeyi ziyaretin hac ibadetinin mütemmim cüzü olduğu ifade edilmektedir (BOA, Y.PRK.AZJ, 51/70). ${ }^{9}$ Yine İstanbul'da bulunan camileri ve kutsal makamları ziyaret etmek de sebepler arasında yer alsa da (BOA, Y.PRK.AZJ, 51/71), temel neden İstanbul'un hilafet merkezi olmasıdır denilebilir. XX. yüzyıl başlarında Kaşgar ileri gelenlerinin Sultan II. Abdülhamit'e sundukları bir yazıdan anlaşıldığı kadarıyla halifeye bu derece bağlılık Rusya'nın hoşuna gitmemekte ${ }^{10}$ hatta hacıların İstanbul'a uğramadan Hicaz’a gitmelerinin yolları aranmakta, Odesa, Sivastopol gibi Rus limanlarından İstanbul'a gitmeye çalışan hacılar doğrudan vapurlar ile Hicaz’a gönderilmekte idi. Rusya Hicaz’a gidişte İstanbul'a uğratmadığ hacıları dönüşte de uğramalarını engellemek için aynı vapurlarla Rus iskelelerine zorla taşımakta idi. Rusya yaşattığı bu zorluklara ilave olarak Kaşgar'da yaşayan Türklerle hiçbir siyasi bağı olmamasına rağmen vize işlemlerini de üzerine almıştı. Vize işlemleri için Rus Hükümeti tarafından alınan pasaportlar gecikmeli olarak verilmekte, hatta bu gecikme haftalarla ifade edilmektedir. Rusların bu muamelesi Kaşgarlı Türklere kendilerinin esir oldukları zannını bile vermektedir (BOA, Y.PRK.AZJ, 51/71). 1906 yılında yaşanan bu sıkıntılar Kaşgarlı hacıları kendi sorunlarını kendilerinin çözmesi yoluna itmiştir. 
Kaşgarlı hacıların sıkıntılarının esas sebebi Çin hükümetine ait İstanbul'da bir elçilik olmamasıdır. Bu sıkıntıyı gören Kaşgarlı Hacı Musa Efendi etrafının destek ve isteği ile kendisini Şeyhülhac ilan etmiştir. Bu gayrı resmi görevlendirme ile Kaşgarlı hacılar sıkıntılarından kurtulmuştur. Osmanlı Hükümeti ise şüphe ile karşıladığı şeyhülhaclık kurumunu Kaşgarlı Hacıların zor durumda kalmasını istememesi sebebiyle kabul etmiştir (BOA, ZB, 318/10).

XIX. yüzyıldaki kayıtlarda açık bir şekilde ifade edilen hilafet merkezi ziyaretinin hac sürecinin bir parçası olarak değerlendirilmesi durumu, önceki yüzyıllarda nasıldı sorusunun yanıtını ise net bir şekilde vermek güçtür. Fakat, XVI. yüzyılda Astrahan'ın Rus egemenliğine girmesiyle birlikte, şartlar itibariyle bir nevi zorunluluk halinde başlamış olan bu uygulamanın, zaman içinde bir gelenek haline gelmiş olması muhtemeldir. Bir kısım Orta Asyalı şeyh ve dervişlerin hac yolculuklarına dair kayıtların İstanbul'u da içermesi, Osmanlı hilafetiyle birlikte İstanbul'un da Türkistanlı hacılar için haccın bir parçası gibi görüldüğü fikri oluşturmaktadır. ${ }^{11}$ Böylelikle, bir taraftan dini bir nitelik taşıyan hac yolculuğu, İstanbul'un da ziyaretiyle hilafete dönük teveccühü de somut bir hale getirmiş, bunun yanısıra Türkistan coğrafyası ile Osmanlı Devleti arasındaki siyasal ve kültürel bağların devamında da merkezi bir rol almıştır denilebilir.

\section{Hicaz Yolunda İstanbul ve Türkistanlı Hacıların İstanbul Tecrübeleri}

Türkistanlı hacı adaylarının hac yolculuklarında böyle bir konuma sahip olan İstanbul, hem hac öncesinde hem de hac sonrasında söz konusu hacı adaylarını ağırlamaktaydı. Yukarıda bahsi geçen güzergâhları izleyerek İstanbul'a gelen Türkistanlı hacılar bir müddet burada kalırlardı. Bu uzun, yorucu ve aynı zamanda tehlikeli yolculuğa Türkistan'ın her kesiminden insanlar çımakta idi. Bunların arasında halktan kişiler, âlimler ve dervişler olduğu gibi tüccarlar ve üst düzey yöneticiler de bulunmakta idi (Alpargu, Yazıcı ve Yavuz 2014: 410). ${ }^{12}$ Gelen ziyaretçilerin çeşitliliği hakkında Başbakanlık Osmanlı Arşivi’nde çok sayıda belge mevcuttur. Üst düzey devlet görevlileri ve elçilik heyetleri genellikle bir Osmanlı bürokratının evinde misafir edilirdi (BOA, A.MKT, 4/2). Misafirlikleri esnasında gerekli nakit ve gıda ihtiyaçları devlet tarafından karşılanmakta idi (BOA, C.HR, 8927). Bu ihtiyaçlarının dışında elçilik heyetlerinin gönlünü almak kabilinden hac dönüşünde İstanbul'da elçi ve maiyetine kürkler hediye edildiği görülmektedir (BOA, C.HR, 6840). 1826 yılında esas gayesi hacca gitmek olan Buhara elçisi Mehmed Fazıl'a, 
İstanbul'a geldiğinde kısa bir program yapılarak bir miktar nakit yardım yapılması, Türkistan'dan hacla bağlantılı olarak gelen elçi ve devlet görevlilerine dönük iyi niyet ve misafirperverliğin bir başka örneği olarak gösterilebilir (BOA, HAT, 1418/57993).

Üst düzey devlet görevlilerinin yanısıra, Osmanlı Devleti bölgenin dini ve siyasi bakımdan itibarlı kişilerine de yardımlarda bulunurdu. Bu yardımlar genellikle söz konusu kişilerin istekleri üzerine belli miktarda nakdî ödeme şeklinde gerçekleşirdi (BOA, A.AMD, 4/11, A.MKT.NZD, 30/75, İ.HR, 2098). Örneğin Buhara’nın önemli âlimlerinden ve Nakşibendî Şeyhi Süleyman Efendi bunlardan birisidir. Süleyman Efendi hac niyetiyle 1855 yllında Urfa'ya ailesi ve 60 kadar müridi ile birlikte gelmiş fakat buradan ileriye gidecek imkânı kalmamıştır. Kendisinin talebi üzerine Şam’a seyahatlerine yetecek kadar nakit para verilmiştir (BOA, İ.MVL, 347/15045). Nakdî yardım, bir kısım itibarlı din adamlarına ise günlük ihtiyaçları kadar yapılıyordu (BOA, A.MKT.NZD, 353/7).

Bazı Türkistanlı hacı adayları da Hicaz’a gitmek için İstanbul'a geldiklerinde maddi bir talepte bulunmamakla birlikte birtakım iş ve işlemlerinde yaşadıkları sıkıntılarının giderilmesi isteğinde bulunuyorlardı. Bürokratik işlerinde kolaylık sağlanması şeklinde gerçekleşen bu desteğin başında gümrükte usulsüz vergi alımının engellenmesi ile beraberlerinde getirdikleri eşyalarının incelemeden muaf tutulması sayılabilir (BOA.DH.MKT, 677/1, DH.MKT, 1320/12). Ayrıca, maddi yardım talebinde bulunmadıkları halde Osmanlı merkezî yönetimi tarafından itibarlı konumları sebebiyle bazı Türkistanlı hacılara gerekli kolaylığın gösterilmesi hakkında Mekke Şerifi'ne, Şeyhülharem'e, valilere emirler de gönderilmiştir (BOA, A.MKT, 21/82, HR.MKT, 367/99). Buhara hâkiminin yeğeni gibi bazı kişilere de talepleri olmadığı halde gönülleri alınmak düşüncesiyle adamları ile birlikte binebilmeleri için vapurdan yer ayırtılmışır (BOA, HR.MKT, 46/78). 1781 yılında İstanbul'a gelmesini müteakip hacca gitmek üzere yola çıkan Buhara elçisine ücreti devlet tarafından karşılanmak üzere üst düzey bir saray görevlisi mihmandar tayin olunmuştur. Elçinin 14 adamının da binek hayvanı, çadır ve tahtırevan ihtiyaçları karşılanmışıı (BOA, C.HR, 8283, C.HR, 8500).

Resmi devlet görevlisi veya özel bir statüsü olmayan bazı hacı adayları hanlarda kalır, bazıları da cami ve tekkelerde barınırlardı (BOA, DH.MKT, 1299/26, DH.MUI, 53/34). Hatta bu konaklama süresi savaş gibi sebeplerle yıllarca 
sürebilirdi. Örneğin Seyyid Celâl Efendi I. Dünya Savaşı’nın çıkması sebebiyle Hicaz’a gitmek niyeti ile geldiği İstanbul'da dört sene boyunca Üsküdar Özbekler tekkesinde ikamet etmiştir. Bu süre zarfında geçimini seyyar tespih satıcılı̆̆ı yaparak sağlamıştır. Tesbih ticaretini oldukça ilerleten Celal Efendi'nin Konya'da ticari faaliyet izni için yaptığı talep, onun bu faaliyetinin boyutunu göstermesi açısından dikkate değerdir (BOA, DH. EUM. 5.Şb, 70/17).

Aciz kategorisinde değerlendirilen Türkistanlı hacı adaylarının ise ücretsiz olarak kutsal topraklara gönderildiği anlaşılmaktadır (BOA, Y.MTV, 225/36). İstanbul'a gelmeyi başarmış fakat daha ileri gitmeye imkânı kalmayan hacı adayları başvuruları halinde bedel ödemeden devletin sağladığı imkânlar ile kutsal topraklara gönderilmekte idiler (A.DVN, 83/3, A.MKT, 7/47, MV, 180/8). Örneğin 1909 yılında Kaşgar'dan yola çıkıp Baküde paraları gasp edildikten sonra İstanbul'a yürüyerek gelmek zorunda kalan Hacı Mansur oğlu Abdülfettah, Hızır ve Hacı Mehmed Cidde'ye kadar ücretsiz olarak gönderilmişlerdir (DH.MUİ, 43-1/44). Bununla birlikte, nadirattan da olsa İstanbul'a kadar gelmiş bazı hacı adaylarının maddi imkânsızlıklar sebebiyle Hicaz’a gitmekten vazgeçip memleketlerine dönmek istedikleri de görülmektedir (BOA, DH.MB.HPS. M, 10/50).

Hac için İstanbul'a gelmiş Türkistanlı hacı adaylarına bu tür yardımlar söz konusuyken, zaman zaman da Osmanlı Devleti'nin onların katkı ve desteklerini aldığı durumlar da söz konusudur. Kayıtlarda karşılaşılan bu türden bir örnek, istihbarat bakımından istifade edildiğini göstermesi açısından kıymetlidir. 1790 yılında İstanbul'a gelen iki Özbek'ten Rusya'nın durumu hakkında alınan bilgi padişaha sunulmuştur (BOA, HAT, 193/9542).

Türkistanlı hacıların önemli bir kısmı Osmanlı Devleti'nin maddi ve manevi yardımları ile Hicaz'a gitmekte idiler. Ancak bir kısmı da maddi yardım almadığı gibi kutsal mekânlara seyahatlerinde yanlarında kıymetli hediyeler de götürmüşlerdir. 1784 yılında Buhara'dan İstanbul'a gelen Muhammed Zakir yanında getirdiği hediyeleri Padişah'a takdim etmiş, Padişah da ona çeşitli hediyeler vermiştir. Muhammed Zakir'in elmas, yakut ve zümrütlerle hazırlanmış bir avizeyi Ravza-i Mutahhara’ya hediye etmek üzere hazırlattığı anlaşılmaktadır (BOA, HAT, 16/723-B). Mekke'nin kapısı mesabesinde olan Cidde şehrinde Türkistan'dan gelen hacıların konaklaması için Buharalı Şeyh Süleyman Efendi tarafından 1877 yılında 600 alıı harcanarak inşa edilen 19 
hücreli zaviye, Türkistanlı ileri gelenlerin hac yolculuğu için yaptıkları harcamalara örnek olarak gösterilebilir (BOA, Y.PRK.AZJ, 1/72, ŞD, 2417/32).

\section{Hicaz'dan Dönüş Yolunda İstanbul}

Türkistanlı hacı adaylarının İstanbul ziyaretlerinin ardından gerçekleştirdikleri hac ibadetlerinin tamamlanmasının ardından istikametleri yine İstanbul'dur (BOA, A.DVNS.MHM.d, 82/96). ${ }^{13}$ Osmanlı Devleti' nin klasik dönemi olan XVI. yüzyılda Türkistanlı hacılara dönüş yolunda vatanlarına kolaylıkla ulaşabilmeleri için Divan-1 Hümayun'dan yol emri verilmekte idi. Bu emirde Türkistanlı hacıların yol üzerinde bulunan tüm idareciler tarafindan korunması talimatı yazılı idi (BOA, A.DVNS.MHM.d, 21/598). Bu usulün XIX. yüzyıl başlarında da devam ettiği görülmektedir. Hac dönüşünde yaşanan olumsuzluklara çözüm olması için verilen belgenin yolculuk esnasında önemli kolaylıklar sağlayacağı aşikârdır (BOA. C.HR, 277).

Bununla birlikte XX. yüzyıl başlarına gelindiğinde, Türkistanlı hacıların dönüş yolunda önemli bir sorun olarak vize mevzusu çıkmaktadır. Vize işlemlerinin hangi ülke tarafından yapılacağının belirsizliği, Osmanlı kurumları arasında da kendisini göstermiştir. Yukarıda, Osmanlı-Rusya ilişkileri bağlamında bahsi geçen Kaşgarlı hacıların vizelerine ilişkin durumu hakkında detaylı bilgiye sahibiz. Dâhiliye Nezareti, Kaşgarlı hacıların vize işlemlerinin Rus konsolosluğu tarafından yapılması için Hariciye Nezareti'nin aracılık yapmasını istemiştir. Bu istek üzerine Hariciye Nezareti konuyu İstişare Odası'na havale ederek bir değerlendirme istemiştir. İstişare Odası yaptığı değerlendirmede, Osmanlı topraklarında seyahat veya ikamet eden Çin tebeasının işlemlerinin Rusya Konsolosluğu tarafından yapılması hakkında bir anlaşma ya da karar olmadığını belirtmiştir. Böyle bir karar olmamasına istinaden Çin tebaası olan Kaşgarlılar'ın istekleri halinde memleketlerine Rusya yolu ile dönüşlerinde, Rus konsolosların pasaportları ücretsiz olarak vize etmekten başka çaresinin olmadığı ifade edilmiştir. Hatta Rusya Konsolosluğunun Çin tebeasına pasaport da veremeyeceğinin altı çizilerek pasaport verilmesi gerekirse istekliye tebaası olduğu devletin isminin yazılması şartı ile Osmanlı Hükümeti tarafindan verilebileceği görüşü zikredilmektedir (BOA, DH.SN.THR, 33/66). Osmanlı Hükümeti pasaportunu kaybeden Türkistanlı hacıların yeni pasaport edinmelerinde karşılaşacakları masraflar için karşılıksız para da vermekte idi (BOA, BEO, 1207/90505). 
Türkistan'dan Hicaz'a yapılan seyahatin uzunluğu sebebiyle bazen idarecilerin ölümleri sebebiyle yaşanan protokol karmaşası, hac dönüşü bir başka bürokratik sorun olarak karşımıza çıkmaktadır. 1819 yılında hac görevini tamamlayarak İstanbul'a uğrayan Buhara elçisi Mirza Fazıl ülkesine döndüğünde götürmek için padişahtan bir mektup istemiştir. Halife tarafından gönderilecek mektup pek tabii olarak gönderilen kişinin saygınlığına önemli katkılar sağlayacaktır. Buhara elçisi Mirza Fazıl yola çıktığında Buhara Hâkimi Haydar Şah vefat etmiş, yerine oğlu geçmiştir. Bir müddet sonra oğlu da vefat etmiş onun yerine diğer oğlu Nasrullah hâkim olmuştur. Ancak yeni hâkim Osmanlı padişahına bağlılık ve dostluğunu içeren ilk mektubu göndermediği için padişahın elçi ile bir mektup göndermesi teamüller açısından uygun değildi. Padişah teamüle rağmen elçinin boş gitmemesi için istenen mektubun hazırlanmasını ve bir de elçilere verilmesi adet olan yol harçlığının ödenmesi hakkında karar vermiştir (BOA, HAT, 782/36608).

Bu tür bürokratik sorunlarla birlikte, Türkistanlı hacıların Hicaz'dan dönüşleri sonrasında yaşadıkları ve oluşturdukları küçük çaplı ekonomik ve toplumsal sorunlar da vardır. Hac öncesi İstanbul'a gelişlerinde yaşananların bir benzeri hac sonrasında da yaşanmaktaydı denilebilir. Buharalı Kargìnın durumu, hacca gitmek niyetiyle İstanbul'a gelip I. Dünya Savaşı'nın başlamasıyla orada dört yıl kalmak zorunda kalan Seyyid Celâl Efendi’nın durumuyla parallellikler taşır. Seyyid Celâl'in aksine hac dönüşü I. Dünya Savaşı'na yakalanan Buharalı Kargı, bu nedenle memleketine dönememiştir. Hacı Kargı geçimini sağlamak için Şam, Halep ve Eskişehir'de bekçilik gibi işlerde çalışarak hayatını idame ettirmiştir. Nihayet Balıkesir'de zanlı olarak yakalanmış, bir belgeye sahip olmadan Osmanlı topraklarında yaşaması mahzurlu görüldüğünden kendisine ikamet tezkiresi verilmiştir (BOA, DH.EUM.5. Şb, 43/30).

Yine hac öncesi olduğu gibi dönüş yolunda İstanbul'a ulaşan hacılardan imkânları yetersiz olanları barınma ve beslenme gibi sorunlar beklemekte idi. Konaklama imkânı olmayan hacılar Sultanahmet, Ayasofya ve Eyüp camilerinin avlularında taşlar üzerinde kalmakta idiler. Türkistanlı hacılar olumsuz hava şartlarına karşı korunaklı olmayan cami avlularında yağmur altında ve çamur içinde yaşamakta kendilerine uzanacak yardım elini beklemekte idiler. Bu durum camileri ziyarete gelen turistlerde Osmanlı Devleti hakkında olumsuz kanaat oluşmasına sebep olmakta idi. 1910 yılı Mayıs ayında 87 hacı yukarıda saydığımız zor şartlar altında mücadele ederlerken durum Os- 
manlı bürokrasisi tarafından fark edilmiş, hacıların Şangay’a giden bir gemi ile gönderilmeleri için gereken maliyet devlet tarafından karşılanmıştır (BOA, DH.MUİ, 93/43). Yine İstanbul'a gelip maddi imkânı olmayan hacıların çeşitli Karadeniz limanlarına ücretsiz gönderildiklerine dair kayıtlar mevcuttur (BOA, A.DVN, 17/48, A.MKT, 7/62).

\section{Sonuç}

XVI. yüzyılda Hicaz bölgesinin Osmanlı Devleti kontrolüne geçmesiyle birlikte, hac ibadetinin organizasyonu ve güvenliği Osmanlı padişahlarının sorumluluğu haline gelmiştir. Bu yaklaşım çerçevesinde Mekke ve Medine'nin "hâdim"i sıfatını taşıyan Osmanlı sultanları, hac ibadetinin kolaylıkla yapılabilmesi için tüm kaynaklarını harekete geçirmiştir.

İmkânların kullanımı konusunda da adalet prensibi ile hareket etmiş, ekonomik ve siyasi olarak ciddi bir beklentisi olmamasına rağmen kilometrelerce uzaklardan İstanbul'a gelen Türkistanlı hacılara, hem Osmanlı tebaası hem de başka devletlerin tebaası olan hacı adaylarına yaptığı gibi devletin tüm idari ve maddi imkânlarını seferber etmiştir.

Osmanlı Devleti'nin Türkistan dışındaki topluluklar için hac ibadetinin kolaylaştırılmasına yönelik kolaylaştırıcı ve yardımsever tutumunda siyasi beklentilerin etkisi olduğu söylenebilir. Ancak Türkistan'la ilişkilerinin başladığ XVI. yüzyılın ortalarından yıkılışına kadar geçen süre zarfında ciddi bir siyasal birliktelik olmamıştır. Bu sebeple Hicaz’a gidiş ve dönüşte Türkistanlı hacılara sağlanan imkânların sebebi olarak devletin ahlaki ve idari anlamda ulaştığı anlayış gösterilebilir. Bununla birlikte, Türkistanlı hacıların İstanbul'da bulunan halife ve kutsal mekânları ziyaret isteği Osmanlı Devleti'nin hazırladığı ortam sayesinde bu şehri Hicaz yolculuğunda vazgeçilmez durak haline getirmiş, "ziyâret-i makâm-1 Halîfeyi” bir nevi "tetimme-i Hacdan” addetmeleri sonucunu doğurmuştur. 


\section{Açılamalar}

1 Hilâfetin Osmanlı Devleti'ne geçişiyle ilgili literatürde farklı yaklaşımlar söz konusudur. Bu çerçevede, Osmanlı sultanının tüm İslam dünyasının halifesi olduğu iddiasının Kanunî döneminde esas olarak ifade edilmeye başlandığı, Yavuz döneminde hilafetin Osmanlılar'a geçişi konusunun ise 18. yüzyılda ortaya çıkan bir durum olduğu ve 19. yüzyıl ile birlikte siyasal olarak daha aktif biçimde kullanılan bir araç olduğu gibi yaklaşımlar, tarih yazımında öne çıkan görüşlerdendir. Bu konudaki literatür değerlendirmesi için bk. Ş. Tufan Buzpınar (2004). "Osmanlı Hilafeti Meselesi: Bir Literatür Değerlendirmesi”. Türkiye Araştırmaları Literatür Dergisi 2 (1): 113-131. Bu konu hakkında gerek Türkçe gerekse yabancı literatürü kapsayan ve yakın zamanda çıkmış revizyonist bir yaklaşım için bk. Giancarlo Casale (2015). "Tordesillas and the Ottoman Caliphate: Early Modern Frontiers and the Renaissance of an Ancient Islamic Institution”. Journal of Early Modern History 19 (6): 485-511. Faroqhi, hac güvenliği kapsamındaki önlemlerin, Hicaz bölgesindeki Osmanlı varlığının devamında temel bir rol oynadığını ifade eder.

Bu kavram hakkında daha detaylı bilgi için bk. Münir Atalar (1995). "Emîr-i Hac". Islam Ansiklopedisi. C. 11. 131-133.

$4 \quad$ McChesney, Türkistanlı hacıların kuzey güzergâhını tercihlerinin temel sebebi olarak Safevi Devleti'ni gösterir.

5 Konunun Osmanlı-Rus ilişkileri bağlamında detaylı bir değerlendirmesi için bk. Halil İnalcık (1948). "Osmanlı-Rus Rekabetinin Menşei ve Don-Volga Kanalı Teşebbüsü (1569)”. Belleten 46 (12): 349-407.

6 XV. yüzyıldan XIX. yüzyıla kadar çeşitli çağdaş kaynaklardan Osmanlı'da hac yolculuğunun günlük detaylı tasviri için bk. Menderes Coşkun (1999). "Osmanlı Hac Seyahatnamelerinde Hac Yolculuğu”. Osmanlılar. C. 4. Ankara: Yeni Türkiye Yay. Kaynaklarından anlaşılacağı üzere, Coşkun'un makalesi, esas olarak Osmanlı tebeasının hac serüvenine odaklanır.

7 Kütükçü de Karadeniz yolunun tehlikesinin az olmasından dolayı daha çok tercih edildiğini ifade eder.

8 Çarlık Rusya’sının Cidde'deki konsolosunun1893 tarihli raporuna göre, Orta Asya'dan gelen hacıların sayısı 4000 ilâ 7000 arası olarak tahmin edilmekteydi: Daniel Brower (1996). "Russian Roads to Mecca: Religious Tolerance and Muslim Pilgrimage in the Russian Empire”. Slavic Review 55 (3): 571.

9 Belgedeki ifade şu şekildedir: "Ahâlî-i mezkûre, cihet-i câmi‘a-i İslâmiyye olan makâm-1 akdes-i Hilâfet-penâhîye merbûtıyyet-i dîniyye ve ma'neviyyeleri 
oldugu i'tikâd-1 kavîsindedirler. Buna binâ’en, îfâ-yı farîza-i Hacdan mukaddem, makâm-1 akdes-i Hilâfet-penâhîyi ziyâret ile cânib-i Hicâz’a gitmeyi vecầib-i diniyyeden bilürler ve ziyâret-i makâm-1 Halîfeyi tetimme-i Hacdan add iderler."

1870’lerin ortalarında Rus elçilik raporlarında, Rus topraklarından gelen "Çar'ın Müslüman tebeasının giderek artan sayılarda, Arabistan'a gidiş veya dönüş yolunda Osmanlı başkentinde görünmelerinin” beklendiği ifade edilmektedir; Daniel Brower (1996): 571.

11 XVI. yüzyıldan bir örnek olarak Şeyh Hüseyin Harezmînnin İstanbul üzerinden gerçekleştirdiği hac yolculuğuna dair bk. Nurten Kılıç-Schubel (2006). "Rethinking the Ties between Central Asia and the Ottoman Empire: Travels of a Central Asian Shaykh in Ottoman Empire in the 16th Century”. VIII. Uluslararası Türkiyénin Sosyal ve Ekonomik Tarihi Kongresi: Bildiriler. Der. Nurcan Abacı. Morrisville: Lulu Press. 259-272, XIX. ve XX. yüzyıl örnekleri için ise bk. Şarifa Taşeva (2012). "Türkistanlı Hacılar ve Seyyahlar Gözüyle İstanbul”. 7. Uluslararası Türk Kültürü Kongresi: Bildiriler. C. I. Konya. 1037-1050.

12 Alpargu, Yazıcı ve Yavuz Türkistanlı hacıların İstanbul'a uğramasına değinmelerine karşın İstanbul'un Türkistanlı hacıların yolculuklarındaki yerinin altını çizmezler. Bunu genel olarak Türkistan coğrafyası ile Osmanlı Devleti arasındaki tarihsel bağlar ve hac organizasyonunun Osmanlı kontrolünde olmasına bağlarlar.

131617 yılında elçi olarak İstanbul'a gelen ve Kâbe’yi ziyaret ettikten sonra Yemen ve Hindistan yolu ile memleketlerine dönen Buhara Hanı İmamkulu Han'ın elçisi Hacı Abdülbaki ve Belh hâkiminin adamlarından Hacı Ömer'in seyahatleri istisna görünmektedir. 


\section{Kaynaklar}

\section{Başbakanlık Osmanlı Arşivi Belgeleri}

A.AMD, 4/11

A.DVN, $17 / 48$

A.DVN, 83/3

A.DVNS.MHM.d, 21/465

A.DVNS.MHM.d, 21/598

A.DVNS.MHM.d, 7/667

A.DVNS.MHM.d, 7/671

A.DVNS.MHM.d, 7/2723

A.DVNS.MHM.d, 82/96

A.MKT, 4/2

A.MKT, 7/47

A.MKT, 7/62

A.MKT, 21/82

A.MKT.NZD, 30/75

A.MKT.NZD, 353/7

BEO, 1207/90505

C.HR, 277

C.HR, 6840

C.HR, 8283

C.HR, 8927

C.HR, 8500

DH.EUM.5. Şb, 43/30

DH. EUM. 5.Şb, 70/17
DH.MB.HPS. M, 10/50

DH.MUI, 43-1/44

DH.MUİ, 53/34

DH.MUİ, 93/43

DH.MKT, 677/1

DH.MKT, 1320/12

DH.MKT, 1299/26

DH.SN.THR, 33/66

HAT, 16/723-B

HAT, 1418/57993

HAT, 193/9542

HAT, 782/36608

HR.MKT, 46/78

HR.MKT, 367/99

İ.HR, 2098

İ.MVL, 347/15045

MV, 180/8

ŞD, 2417/32

Y.PRK.AZJ, 1/72

Y.PRK.AZJ, 51/70

Y.PRK.AZJ, 51/71

Y.MTV, 225/36

ZB, 318/10 


\section{Kitap ve Makaleler}

Andican, A. Ahat (2009). Osmanlidan Günümüze Türkiye ve Orta Asya. İstanbul: Doğan Kitap.

Alpargu, Mehmet, Serkan Yazıcı ve Fikrettin Yavuz (2014). "Arduous Journey to Hedjaz: Turkestani Pilgrims, the Caliph and Istanbul ( $16^{\text {th }}-20^{\text {th }}$ centuries)". Ankara Üniversitesi Dil ve Tarih-Coğrafya Fakültesi Dergisi 54 (1): 401-416.

Atalar, Münir (1995). "Emîr-i Hac". İslam Ansiklopedisi. C. 11. İstanbul: TDV Yay. 131-133.

Brower, Daniel (1996). "Russian Roads to Mecca: Religious Tolerance and Muslim Pilgrimage in the Russian Empire”. Slavic Review 55 (3): 567-584.

Buzpınar, Ş. Tufan (2004). "Osmanlı Hilafeti Meselesi: Bir Literatür Değerlendirmesi”. Türkiye Araştırmaları Literatür Dergisi 2 (1): 113-131.

Casale, Giancarlo (2015). "Tordesillas and the Ottoman Caliphate: Early Modern Frontiers and the Renaissance of an Ancient Islamic Institution”. Journal of Early Modern History 19 (6): 485-511.

Coşkun, Menderes (1999). "Osmanlı Hac Seyahatnamelerinde Hac Yolculuğu”. Osmanl. C. 4. Ankara: Yeni Türkiye Yay.

Faroqhi, Suraiya (2008). Hacılar ve Sultanlar: Osmanlı Döneminde Hac (1517-1683). İstanbul: Tarih Vakfi Yurt Yay.

İnalcık, Halil (1948). "Osmanlı-Rus Rekabetinin Menşei ve Don-Volga Kanalı Teşebbüsü (1569)”. Belleten 46 (12): 349-407.

Kılıç-Schubel, Nurten (2006). "Rethinking the Ties between Central Asia and the Ottoman Empire:Travels of a Central Asian Shaykh in Ottoman Empire in the 16th Century". VIII. Uluslararası Türkiyenin Sosyal ve Ekonomik Tarihi Kongresi: Bildiriler. Der. Nurcan Abacı. Morrisville: Lulu Press. 259-272.

Kurşun, Zekeriya (1999). “Osmanlı İdaresinde Hicaz (1517-1519)”. Osmanlı. C.1. Ankara: Yeni Türkiye Yay.

Kütükçü, Mustafa (2011). "Rusya'da Haccın Tarihi Serüveni”. Karadeniz-Black Sea 3 (12): 178-190.

Özcan, Abdülkadir (1996). "Hac". İslam Ansiklopedisi. C. 14. İstanbul: TDV Yay. 400-408.

Saray, Mehmet (1984). Osmanl Devleti ile Türkistan Hanlıkları Arasındaki Siyasi Münasebetler. İstanbul.

Taşeva, Şarifa (2012). “Türkistanlı Hacılar ve Seyyahlar Gözüyle İstanbul”. 7. Uluslararası Türk Kültürü Kongresi: Bildiriler. C. I. Konya. 1037-1050.

Uzunçarşılı, İsmail Hakkı (1972). Osmanlı Tarihi. C. 2. Ankara: TTK Yay. 


\title{
Istanbul as a Center of Visit for Turkestani Pilgrims ${ }^{*}$
}

\section{Yusuf Sannay $^{*}$}

\begin{abstract}
Despite the political gaps in time, relations between the Ottoman Empire and Turkestan region endured due to the cultural and religious ties and common historical background. One of the important indicators of these relations is the visit of Istanbul by the Turks from Turkestan region as the center of the Caliphate on their pilgrimage route. Ottoman Empire, as a state policy, ensured the safety and security of the pilgrims from Turkestan region against threatening factors of Iran and Russia and covered pilgrims' accommodation expenses in İstanbul and other expenses during their travels.
\end{abstract}

Based upon archival documents, this article deals with the pilgrims' route to Hedjaz through İstanbul and the policy of the Ottoman Empire on this issue.

\section{Key words}

Ottoman Empire, İstanbul, Turkestan, Turkestani pilgrims, Turkestani envoys, Bukhara, Kashgar.

\footnotetext{
* Date of Arrival: 23 November 2016 - Date of Acceptance: 11 June 2017 You can refer to this article as follows:

Sarınay, Yusuf (2019). "Türkistanlı Hacıların Ziyaret Merkezi Olarak İstanbul”. bilig - Türk Dünyası Sosyal Bilimler Dergisi 88: 1-18.

* Prof. Dr., TOBB University, Faculty of Science and Letters, Department of History - Ankara/Turkey ORCID ID: https://orcid.org/0000-0002-6486-3417 ysarinay@etu.edu.tr
} 


\title{
Стамбул как центр посещения паломниками из Туркестана*
}

\author{
Юсуфр Сарынай
}

\begin{abstract}
Аннотация
Несмотря на то, что политические отношения между Османской империей и Туркестаном не были постоянными, культурные и религиозные связи не прекращались. Важную часть этих отношений составлял маршрут хаджа туркестанских паломников, который пролегал через центр Халифата - Стамбул в обоих направлениях. Османская империя, в свою очередь, предоставляла паломникам безопасный путь (ввиду российского и иранского факторов), а также оплачивала издержки на дорогу и проживание. Статья, основываясь на архивных документах, анализирует путь туркестанских паломников через Стамбул в Хиджаз и политику Османской империи в их отношении.
\end{abstract}

\section{Ключевые слова}

Османская империя, Стамбул, Туркестан, туркестанские паломники, туркестанские представители, Бухара, Кашгар

Поступило в редакцию: 23 ноябрь 2016 г. - Принято в номер: 11 июнь 2017 г.

Ссылка на статью:

Sarınay, Yusuf (2019). “Türkistanlı Hacıların Ziyaret Merkezi Olarak İstanbul”. bilig - Türk Dünyası Sosyal Bilimler Dergisi 88: 1-18.

Проф., д-р, Университет ТОББ, отделение истории факультета науки и литературы - Анкара/

Турция

ORCID ID: https://orcid.org/0000-0002-6486-3417

ysarinay@etu.edu.tr 